\title{
DEVELOPMENT OF THE SYSTEM OF BALANCED SCORECARD FOR ENTERPRISES OF THE PETROCHEMICAL COMPLEX \\ TATNEFT
}

\author{
Anton N. Karamyshev ${ }^{1}$ \\ Gulsina K. Gabdullina ${ }^{2}$ \\ Anatoly Ye. Yakovlev ${ }^{3}$
}

\begin{abstract}
Regional policy in the field of law-making in support of innovation, investment, improvement of interregional and international relations, on the one hand, and implementation of the provisions of the antimonopoly legislation, replenishment of the budget, development of economic, financial, transport and other infrastructure of the region, on the other hand, discloses the content of favourable, and constraining the development of corporate activities conditions that determine the purpose and planned value of indicators of the corporation functioning. Establishment of economic targets from the scientific and practical point of view is only one side of the management function, it is
\end{abstract}

important to organize the accounting, analysis and evaluation of the effectiveness of achieving the goals of the corporation, the results of which serve as the information base for making managerial decisions and adjusting planned activities.Indicators of the effect and efficiency of managing corporations are the subjects of many discussions. At the same time, it is important to understand that attention should be drawn not as much to the results obtained, as to the conditions and factors that determined them. The analysis of cause-effect relationships allows modern corporations to build a system of dependencies, to adjust their development strategy taking into

\footnotetext{
${ }^{1}$ Kazan Federal University.

2 Kazan Innovative University named after V. G. Timiryasov (IEML). e-mail: antonkar2005@yandex.ru. Tel.: +7-960-067-65-50.

3 Kazan Innovative University named after V. G. Timiryasov (IEML). e-mail: antonkar2005@yandex.ru. Tel.: +7-960-067-65-50.
} 
account their territorial affiliation and to apply modern tools for matrix analysis and planning, to which the system of balanced scorecard of Norton and Kaplan can be related.

Keywords: balanced scorecard, holding, enterprises, goals, objectives, indicators, efficiency.

\section{Introduction}

The system of indicators used in making managerial decisions and the system of indicators used in the process of analysing the financial and economic activities of a corporation are fundamentally different. In the first case, it is the desire to achieve the set goals through the management of the enterprise, in the second case it is the need to analyse the activities of the enterprise, to assess its investment attractiveness, etc. [1].

Undoubtedly, the system of indicators for management is characterized by the properties of the system of indicators used for analysis, since analysis is one of the methods of management. At the same time, the scorecard, intended solely for analysis purposes, is often not suitable for management.

The system of indicators can not be limited only by monetary indicators, since the economy of enterprises currently depends to a large extent on factors of completely noneconomic (ecology, social sphere, politics, etc.) that have a significant impact on the holding's economy and, ultimately, its financial results.

Establish the role of a single corporation enterprise, perhaps if we analyse its contribution to the overall strategy using the method of "climbing from the abstract to the concrete. Under a concrete expression of the holding's strategy is understood its mission, its concrete and essential abstraction. The economic activities of enterprises that make up the corporation are data in objectively sensory form abstract phenomena, beyond which, without knowing the essence, it is impossible to comprehend the activities of the whole holding "[1. 246 p.]. Nevertheless, the use of a cascade of indicators of a balanced scorecard allows one to logically establish the relationship between the strategy of each enterprise and the specific general strategy of the 
corporation. Moreover, cascading enables the development of a system of balanced scorecard, both for a single enterprise and for the holding as a whole, "at the same time, clear quantified strategic goals will be set at each level that meet the mission of the entire corporation" [1.248 p.].

\section{Text of article}

Tatneft is a Russian oil company, whose main assets are located on the territory of the Republic of Tatarstan, and business projects are conducted in the domestic and foreign markets. The group of companies of Tatneft PJSC unites oil and gas production, oil and gas refining, petrochemical and gas, oil, petrochemical and petroleum products, as well as a block of service structures. The balanced scorecard will be developed for one of the segments of Tatneft PJSC, a petrochemical complex.

According to the information provided on the official website of the company, the mission of Tatneft PJSC is to strengthen internationally recognized positions and ensure the company's steady development as one of the largest vertically integrated Russian producers of oil and gas, oil and gas products and petrochemicals, thermal and electric energy based on effective management of shareholders' assets, rational use of natural resources and corporate social responsibility. At the same time, it remains unclear strategic goals for an individual enterprise of the corporation, for example, for Nizhnekamskshina PJSC, whose main activity is the production of tires. Cascading in turn allows "to form exactly those goals that, in the process of decomposition from the upper level, will be transferred to the final enterprise, thereby bringing to it the mission of the holding" [1. 248 p.]. Through this mechanism, the task of reconciliation is also being solved, in particular, the transition from the holding's strategy to the strategies of the enterprises that make up its structure.

Petrochemical complex of Tatneft PJSC includes five relatively independent phases, which are presented as independent businesses: production of carbon black; processing, namely the production of tires; performance of repair work; supply and sale of products.

The relationship between the phases presented, functioning under the 
management of Tatneft-Neftekhim, is

shown in Figure 1.

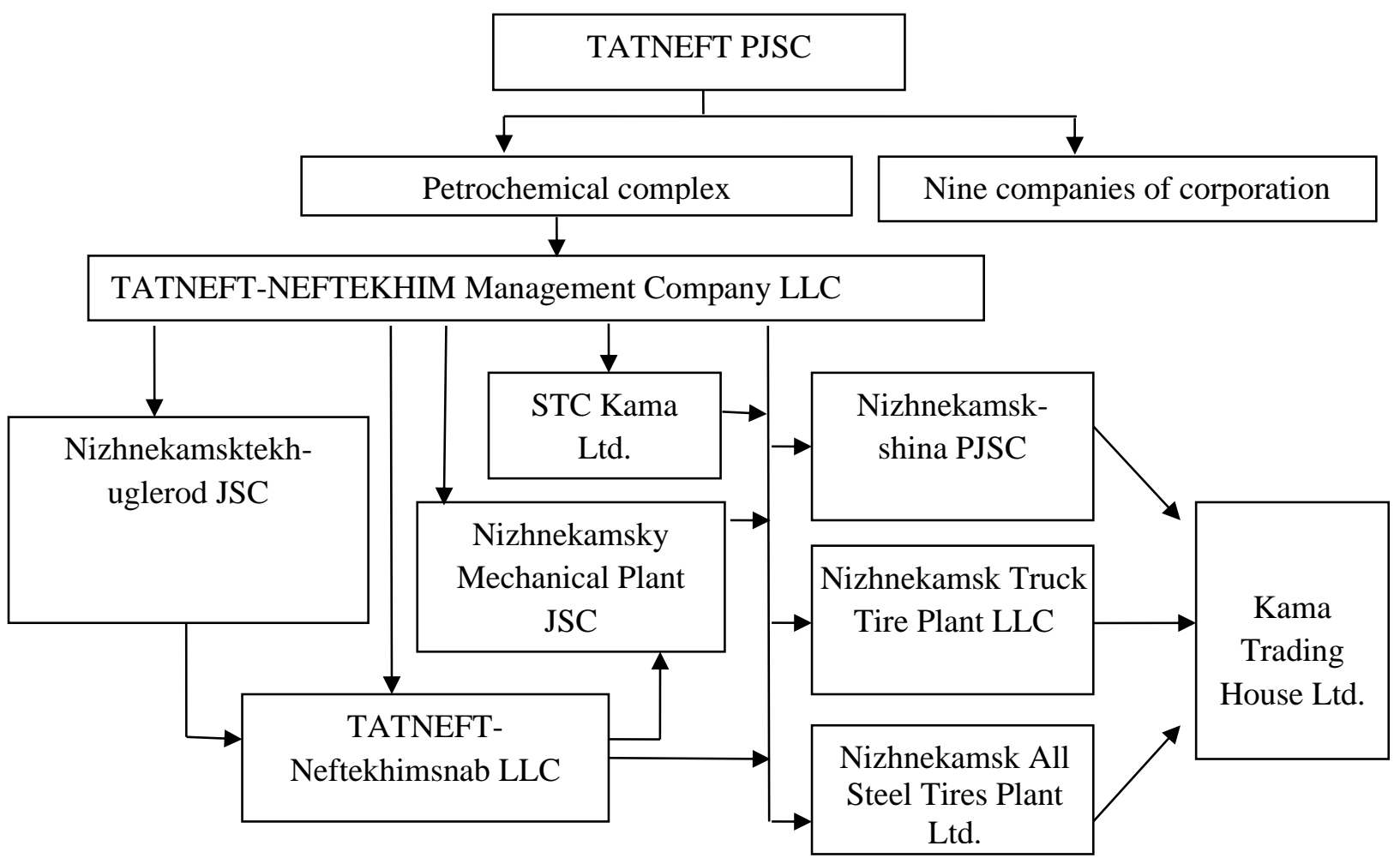

Fig.1. Interconnection of enterprises of the petrochemical complex

Tatneft PJSC

In the petrochemical complex of Tatneft PJSC, a matrix management structure, where conflict situations often arise between production enterprises and intermediary organizations (supply, sales, etc.). The interests of the petrochemical complex enterprises are reflected in plans and budgets $[3,11]$.

Building a system of balanced scorecard for corporate structures begins with the development of a top-level strategic map that expresses the strategy of the whole corporation.

The first level is the development of the "Finance" perspective, then the strategies for the remaining perspectives are consistently developed.

The second level is the definition of "stakeholders" of the contractors of the corporation, when working with which the petrochemical 
complex of Tatneft PJSC achieves its financial goals, receives financial results.

The third level is the definition of business processes. One way to display the business process is to compile a functional model using the IDEFO methodology, a variant of which for the petrochemical complex of Tatneft PJSC is shown in Figure 2.

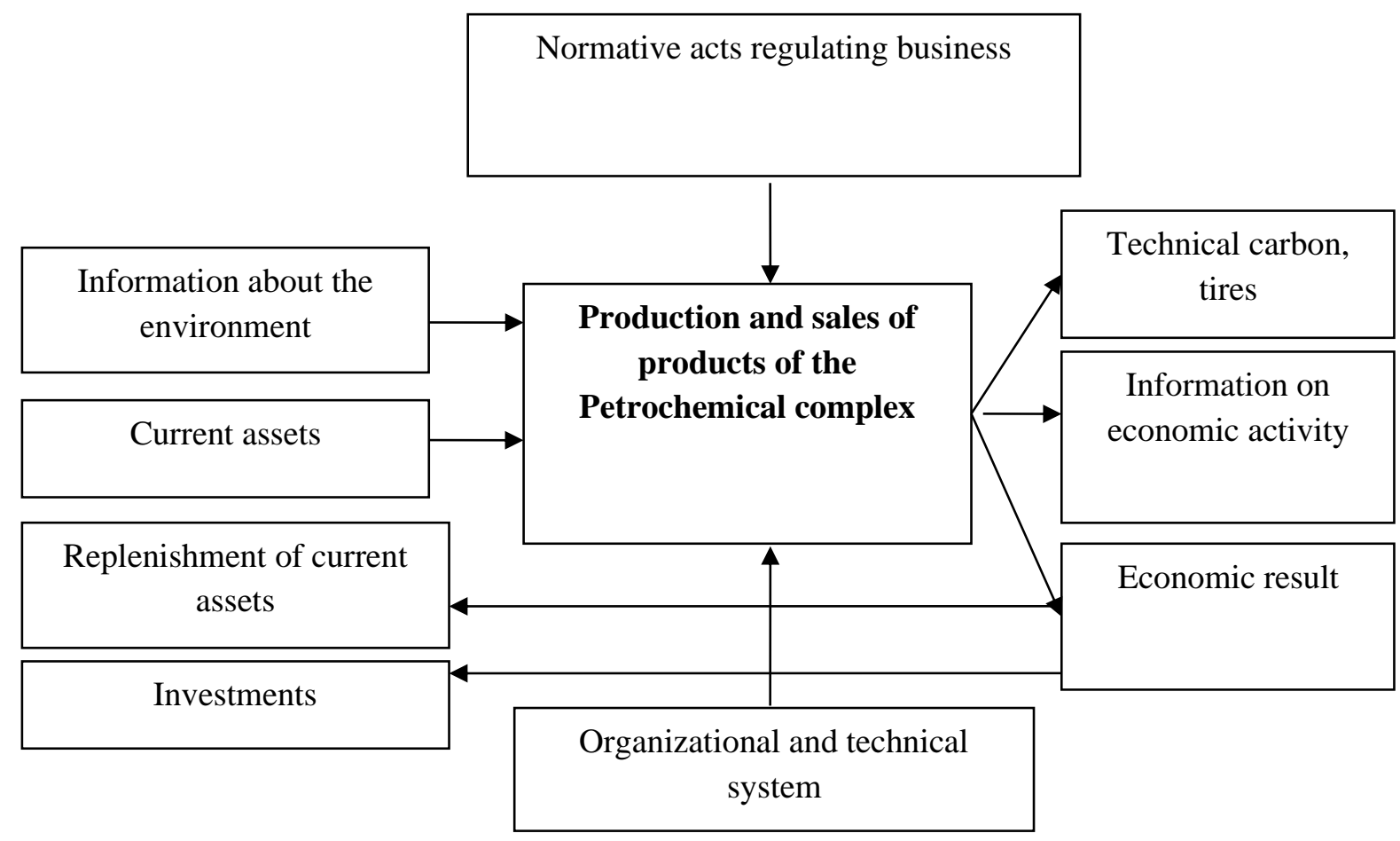

Fig. 2. Main business process of the petrochemical complex

\section{Tatneft PJSC}

The final (fourth) level of development of the strategic card is "the disclosure of shortcomings in the qualifications of employees, the means of labor and the level of technologies that affect the effectiveness of business processes".

According to the described levels, a strategic map of the Tatneft PJSC Petrochemical Complex was constructed (Fig. 3). 
Periódico do Núcleo de Estudos e Pesquisas sobre Gênero e Direito Centro de Ciências Jurídicas - Universidade Federal da Paraíba

V. 8 - $\mathrm{N}^{\mathrm{o}} 05$ - Ano 2019

ISSN | 2179-7137 | http://periodicos.ufpb.br/ojs2/index.php/ged/index

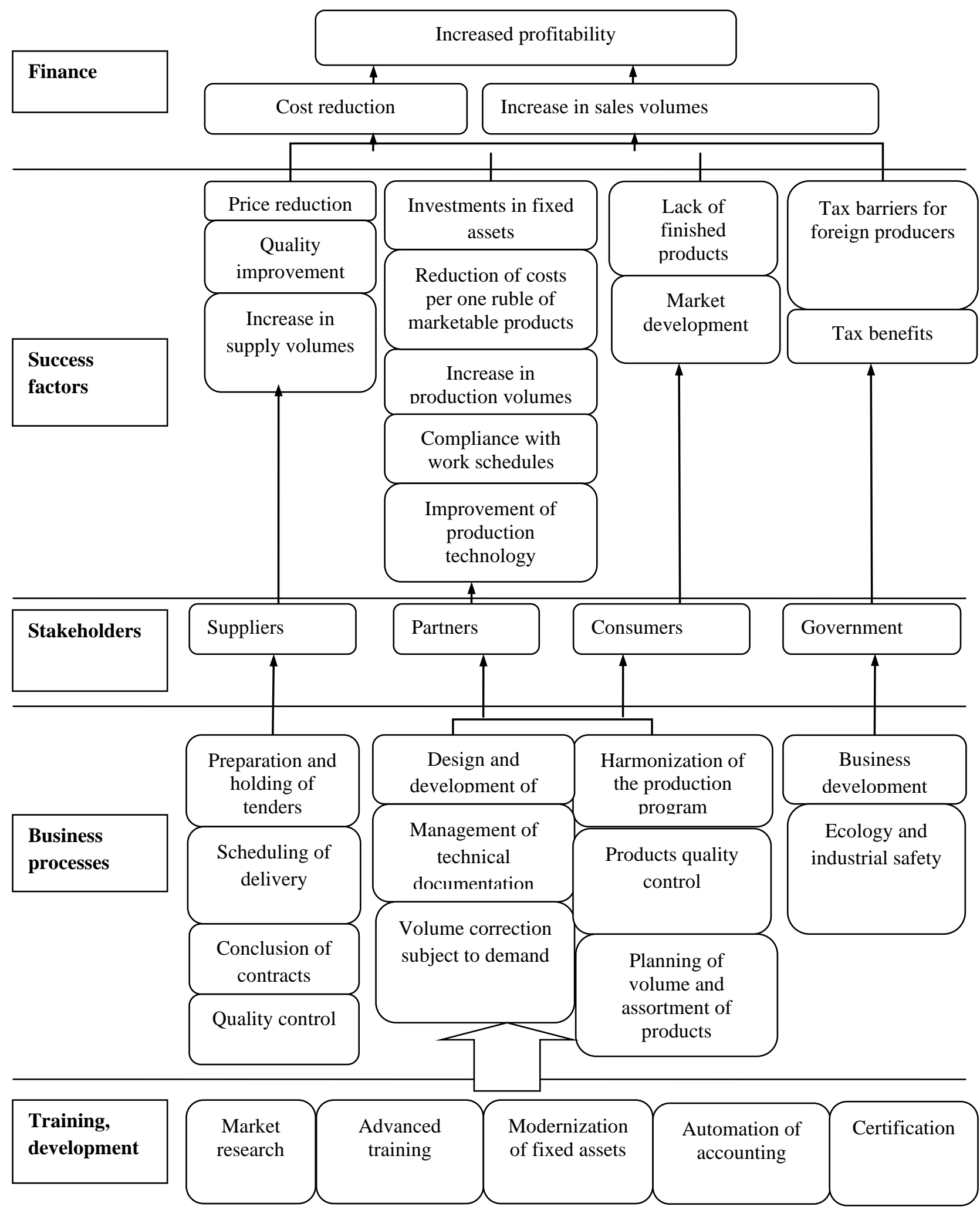


Fig.3. Strategic map of the Tatneft PJSC Petrochemical Complex [4]

This development of the strategic map of the corporation (holding) does not end, but finds its continuation in the development of similar strategic maps for the enterprises that make up its structure.

The construction of a system of balanced scorecard for the main enterprises of the petrochemical complex begins with the formation of the "Holding-Segments" transition table.

First of all, the table introduces the objectives of the level of the corporation, then considers a separate goal for each enterprise and then a decision is made to move the target to the lower level.

After determining all the objectives for the enterprise, they must be connected by cause-effect relations.

The strategic map of TatneftNeftekhimsnab LLC, which provides material resources to the enterprises that are part of the petrochemical complex of Tatneft PJSC, is shown in Figure 4. 


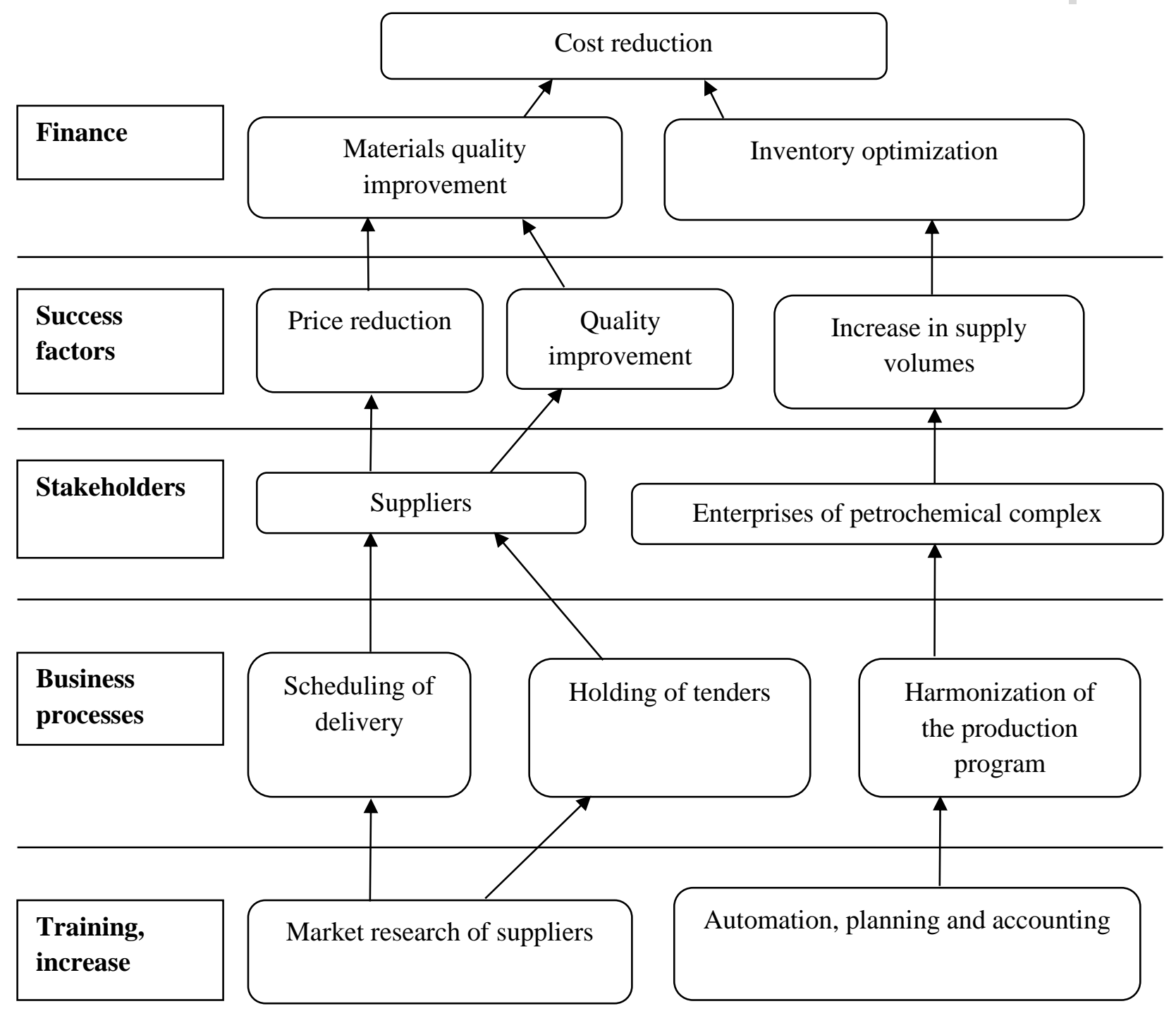

Fig.4. Strategic card of Tatneft-Neftekhimsnab LLC

For each enterprise it is necessary to repeat the whole algorithm of constructing a strategic card in a similar way to the scheme.
The strategic map of the production enterprise of Nizhnekamskshina PJSC, also part of the petrochemical complex of Tatneft PJSC, is shown in Figure 5. 
Periódico do Núcleo de Estudos e Pesquisas sobre Gênero e Direito Centro de Ciências Jurídicas - Universidade Federal da Paraíba

V. 8 - $\mathrm{N}^{\mathrm{o}} 05$ - Ano 2019

ISSN | 2179-7137 | http://periodicos.ufpb.br/ojs2/index.php/ged/index

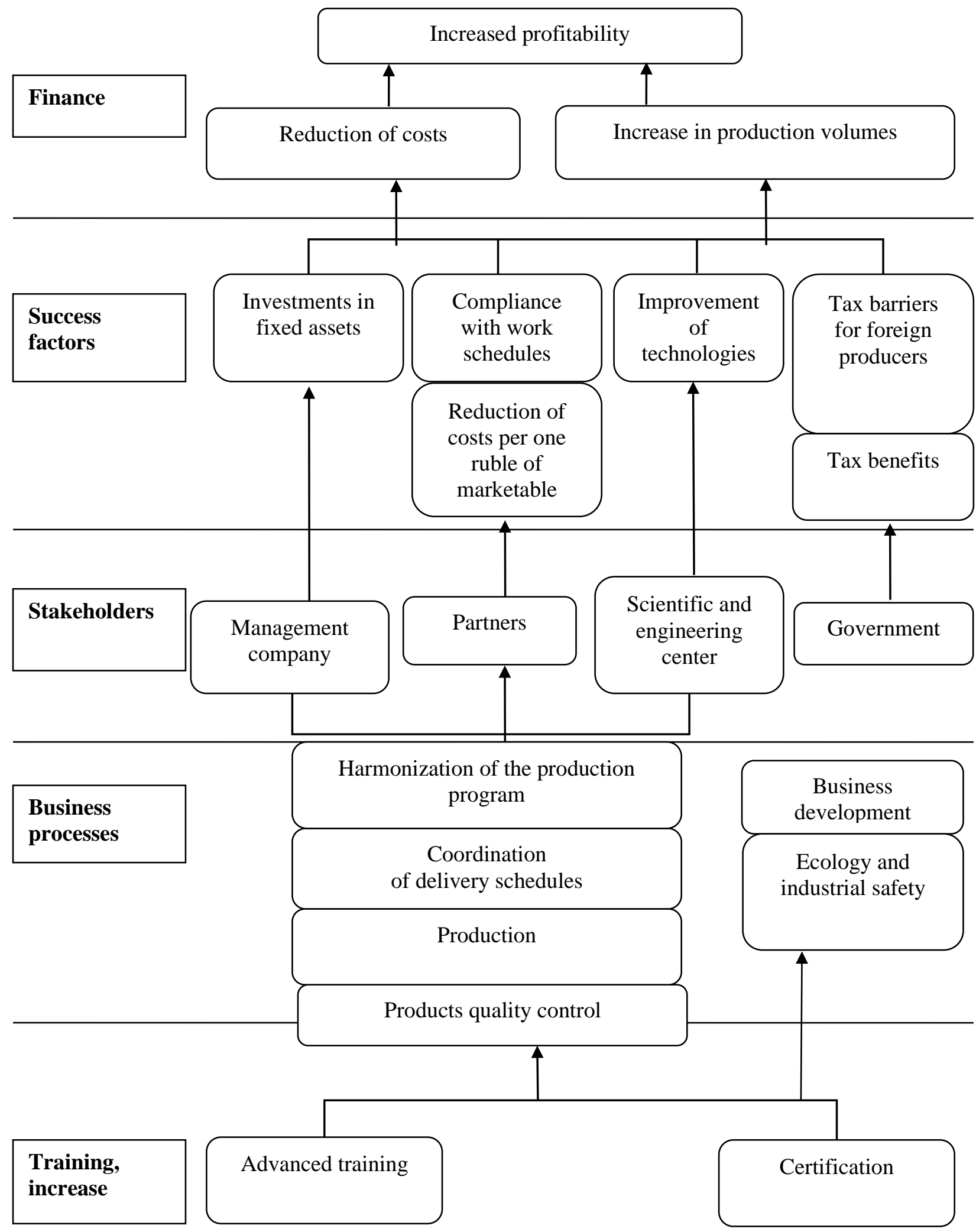

Fig.5. Strategic map of Nizhnekamskshina PJSC 
Periódico do Núcleo de Estudos e Pesquisas sobre Gênero e Direito Centro de Ciências Jurídicas - Universidade Federal da Paraíba

V. 8 - No 05 - Ano 2019

ISSN | 2179-7137 | http://periodicos.ufpb.br/ojs2/index.php/ged/index

The strategic map of KAMA

Trading House, which performs the

function of selling products of the petrochemical complex of Tatneft

PJSC, is shown in Figure 6.

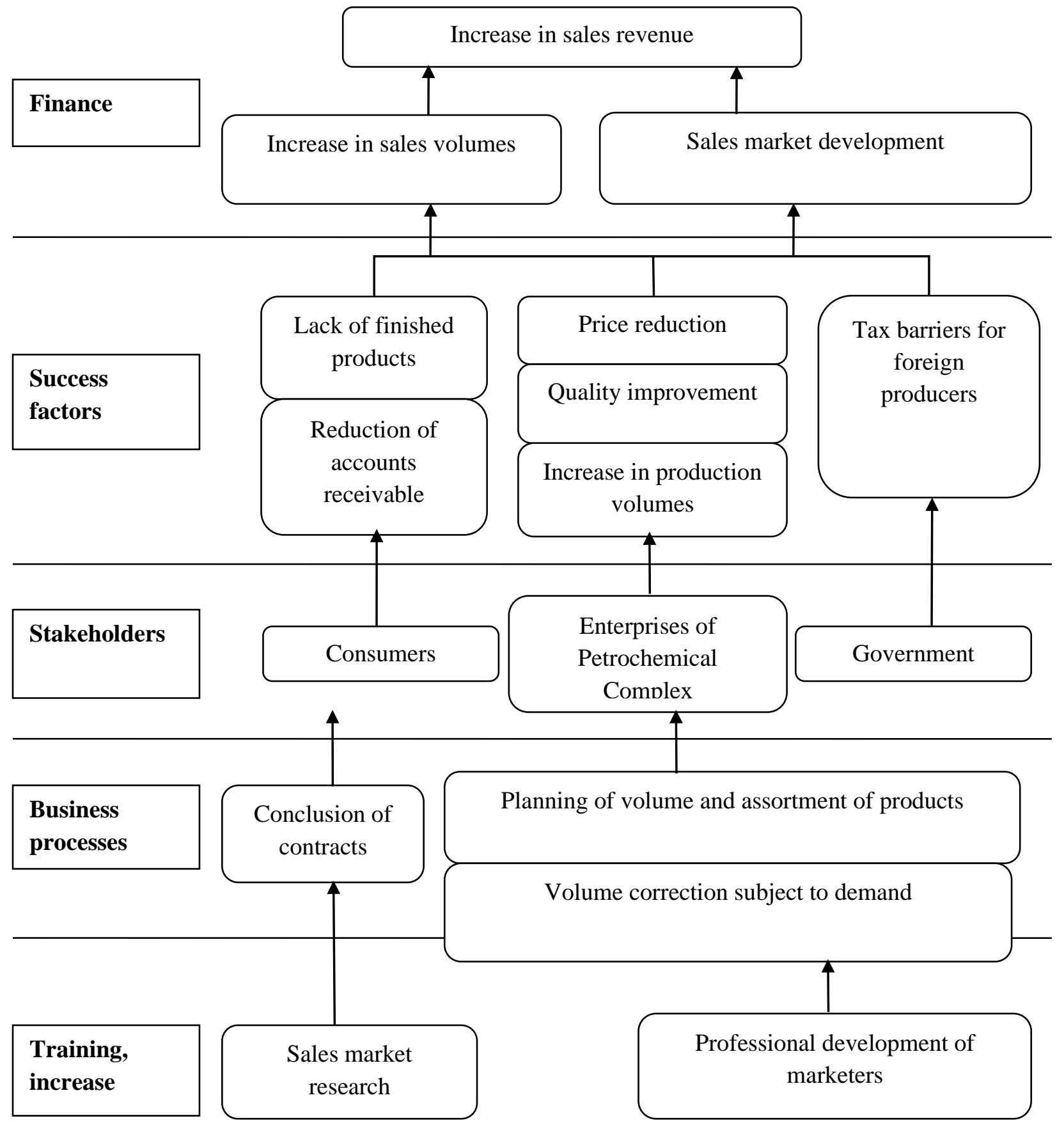


Periódico do Núcleo de Estudos e Pesquisas sobre Gênero e Direito Centro de Ciências Jurídicas - Universidade Federal da Paraíba

V. 8 - No 05 - Ano 2019

ISSN | 2179-7137 | http://periodicos.ufpb.br/ojs2/index.php/ged/index

Fig.6. Strategic map of the Trading House "Kama"

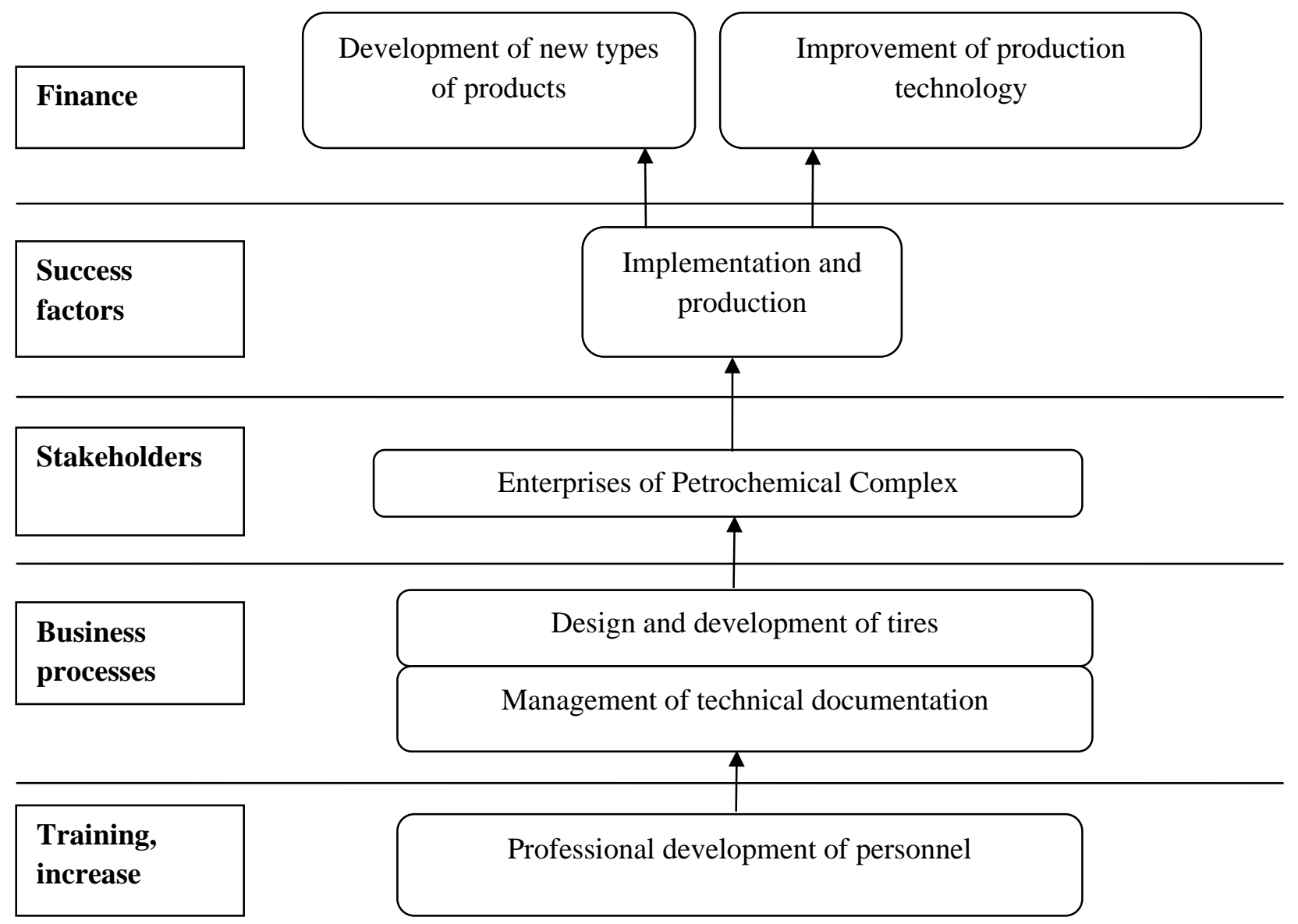

Fig.7. Strategic map of the scientific and technical center "Kama"

After defining the goals and developing a strategic map for each level of management, the transition from established goals to quantitative indicators is performed. This process should be "accompanied by the compilation of a statement where the correspondence between indicators and goals should be indicated" [2] (Table 1).

Table 1 - The goals and indicators of the petrochemical complex of Tatneft PJSC 
Periódico do Núcleo de Estudos e Pesquisas sobre Gênero e Direito Centro de Ciências Jurídicas - Universidade Federal da Paraíba

V. 8 - No 05 - Ano 2019

ISSN | 2179-7137 | http://periodicos.ufpb.br/ojs2/index.php/ged/index

\begin{tabular}{|c|c|c|c|c|c|}
\hline \multirow[t]{2}{*}{ No. } & \multirow[t]{2}{*}{ Prospects } & \multirow[t]{2}{*}{ Goals } & \multirow[t]{2}{*}{ Indicator } & \multicolumn{2}{|l|}{$\begin{array}{l}\text { Target } \\
\text { values }\end{array}$} \\
\hline & & & & value & date \\
\hline 1 & 2 & 3 & 4 & 5 & 6 \\
\hline 1 & Finance & Increased profitability & $\begin{array}{l}\text { Profitability of } \\
\text { production, } \%\end{array}$ & & \\
\hline 2 & Finance & Cost reduction & $\begin{array}{l}\text { Costs per one ruble } \\
\text { of revenue, kop. }\end{array}$ & & \\
\hline 3 & Finance & $\begin{array}{l}\text { Increase in sales } \\
\text { volumes }\end{array}$ & $\begin{array}{l}\text { Growth rate of sales } \\
\text { volumes, } \%\end{array}$ & & \\
\hline 4 & $\begin{array}{l}\text { Success } \\
\text { factors }\end{array}$ & $\begin{array}{l}\text { Reduced input and } \\
\text { output prices }\end{array}$ & Percent change, $\%$ & & \\
\hline 5 & $\begin{array}{l}\text { Success } \\
\text { factors }\end{array}$ & Quality improvement & $\begin{array}{l}\text { Quality coefficient, } \\
\text { reduction of defects }\end{array}$ & & \\
\hline 6 & $\begin{array}{l}\text { Success } \\
\text { factors }\end{array}$ & $\begin{array}{l}\text { Increase in supply } \\
\text { volumes }\end{array}$ & Growth rate, $\%$ & & \\
\hline 7 & $\begin{array}{l}\text { Success } \\
\text { factors }\end{array}$ & $\begin{array}{l}\text { Investments in fixed } \\
\text { assets }\end{array}$ & Renewal coefficient & & \\
\hline 8 & $\begin{array}{l}\text { Success } \\
\text { factors }\end{array}$ & $\begin{array}{l}\text { Reduction of costs per } \\
\text { one ruble of marketable } \\
\text { products }\end{array}$ & $\begin{array}{l}\text { Costs per one ruble } \\
\text { of marketable } \\
\text { products, kop. }\end{array}$ & & \\
\hline 9 & $\begin{array}{l}\text { Success } \\
\text { factors }\end{array}$ & $\begin{array}{l}\text { Increase in production } \\
\text { volumes }\end{array}$ & Growth rate, $\%$ & & \\
\hline 10 & $\begin{array}{l}\text { Success } \\
\text { factors }\end{array}$ & $\begin{array}{l}\text { Compliance with work } \\
\text { schedules }\end{array}$ & Rhythm factor & & \\
\hline 11 & $\begin{array}{l}\text { Success } \\
\text { factors }\end{array}$ & $\begin{array}{l}\text { Improvement of } \\
\text { production technology }\end{array}$ & $\begin{array}{l}\text { Growth rate of } \\
\text { production volumes }\end{array}$ & & \\
\hline 12 & $\begin{array}{l}\text { Success } \\
\text { factors }\end{array}$ & $\begin{array}{l}\text { Lack of finished } \\
\text { products }\end{array}$ & & & \\
\hline 13 & $\begin{array}{l}\text { Success } \\
\text { factors }\end{array}$ & Market development & Market share, $\%$ & & \\
\hline
\end{tabular}


Periódico do Núcleo de Estudos e Pesquisas sobre Gênero e Direito Centro de Ciências Jurídicas - Universidade Federal da Paraíba

V. 8 - No 05 - Ano 2019

ISSN | 2179-7137 | http://periodicos.ufpb.br/ojs2/index.php/ged/index

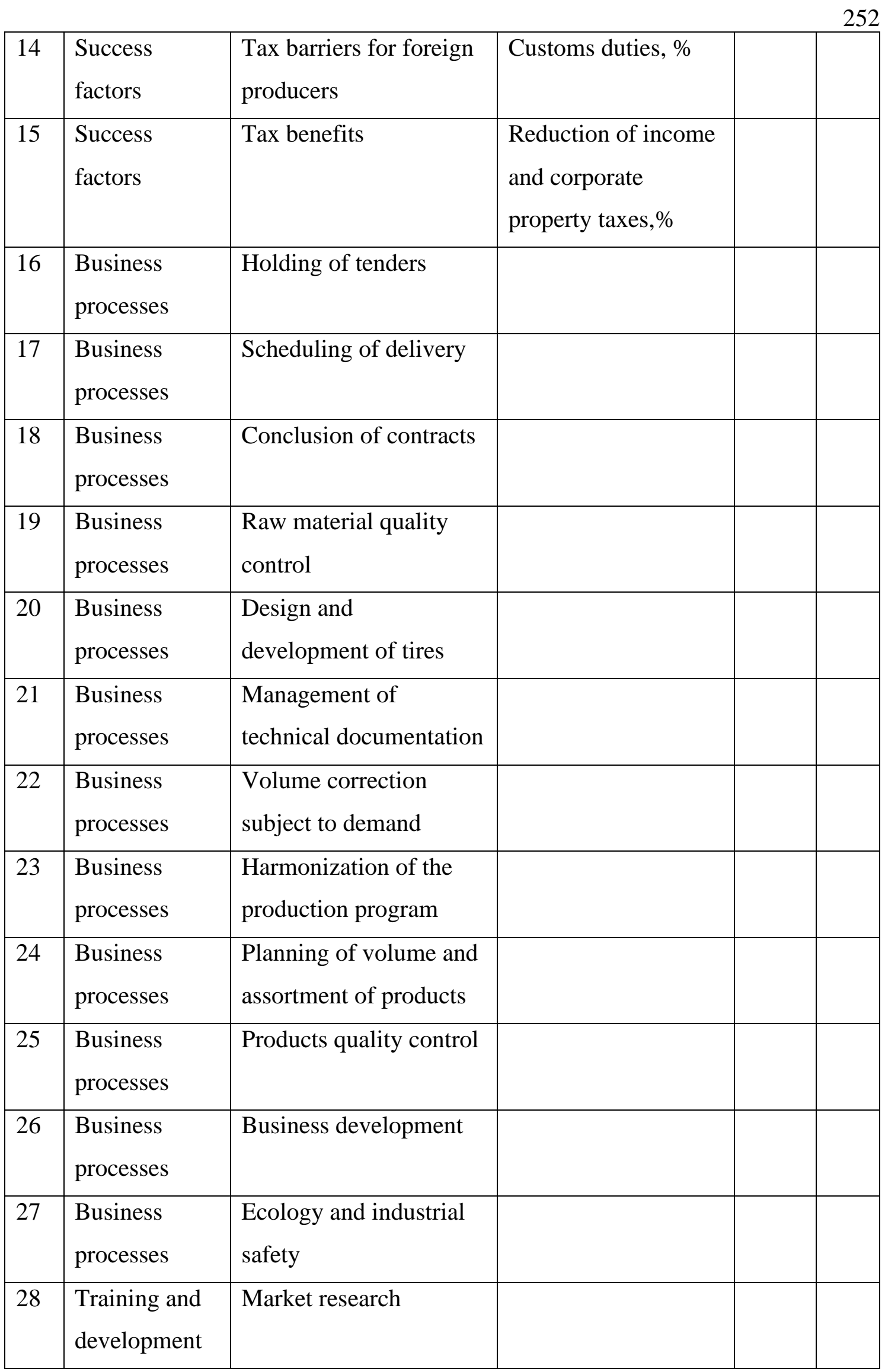


ISSN | 2179-7137 | http://periodicos.ufpb.br/ojs2/index.php/ged/index

\begin{tabular}{|c|c|c|c|c|}
\hline 29 & $\begin{array}{l}\text { Training and } \\
\text { development }\end{array}$ & Advanced training & & \\
\hline 30 & $\begin{array}{l}\text { Training and } \\
\text { development }\end{array}$ & $\begin{array}{l}\text { Production } \\
\text { modernization }\end{array}$ & Wear factor & \\
\hline 31 & $\begin{array}{l}\text { Training and } \\
\text { development }\end{array}$ & $\begin{array}{l}\text { Automation of } \\
\text { accounting }\end{array}$ & & \\
\hline 32 & $\begin{array}{l}\text { Training and } \\
\text { development }\end{array}$ & Certification & & \\
\hline
\end{tabular}

At this stage, the first step in constructing a system of balanced scorecard will be the determination of the indicators for the lower level of the cascade pyramid. The following steps establish a mechanism for consolidating (combining) the lower-level indicators to form the top-level indicators.

The available indicators can be divided into three groups:

1) Indicators characterizing the state;

2) Indicators of use;

3) Indicators that assess the result of economic activity.

The final stage of the development of the entire cascade of balanced scorecard in the holding is the development of strategic measures aimed at achieving the goals.

The main advantage of this system is the ability to assess the result at different levels and in different sections of the organization (functional and linear) within the framework of analysis of financial and economic activity. For example, it can be used to develop effective mechanisms to motivate staff to implement a strategy when determining the dependence of the bonus system on certain performance indicators of an enterprise.

\section{Methods}

In the course of the study, authors used the following methods:

1. The selective analysis of specialized literature with a high citation index for the subject matter indicated in the title of the article. In particular, the experience of applying a system of balanced scorecard in domestic oil companies was studied. 
2. The way to overcome the shortcomings of traditional methods of enterprise performance evaluation is proposed, which are based on the analysis of its financial indicators, which reflect exclusively the financial side of its activity through the use of modern tools of matrix analysis and planning (MAP).

\section{Results and discussion}

The shortcomings of the system of balanced scorecard include:

1) The complexity of adapting the MAP to various conditions of economic activity. So, for example, a system of balanced scorecard developed for a particular enterprise (certain business conditions) will not work efficiently in other economic activities. To a greater extent, this applies to corporations and companies with wide-ranged economic activities.

2) The risk of information leakage. This is due to the fact that in order to understand the chosen strategy, the company's personnel must be informed about all the company's indicators and the mechanism of the company's operation.

\section{Summary}

The development of a system of balanced scorecard allows us to give a more complete assessment of the activities of the enterprise, both in retrospect and in forecasting its future opportunities. This is explained by the fact that the system of balanced scorecard, along with financial indicators, takes into account the system of non-financial indicators, and the results allow assessing the conformity of the activities conducted by the enterprise to its objectives.

\section{Conclusions}

Traditionally, the assessment of the company's activities is based on an analysis of its financial performance, reflecting only the financial side of its activities. These limitations are removed when the potential of the balanced scorecard is realized, which, along with the financial ones, takes into account the system of non-financial indicators, and the results allow assessing the conformity of the activities conducted by the enterprise to its objectives.

\section{Acknowledgements}


The work is performed according to the Russian Government Program of Competitive Growth of Kazan Federal University.

\section{References}

Antonov I.V. (2006). Balanced system of controlling indicators (on the example of oil and gas holding) // Audit and financial analysis. № 1. P.246.

Antonov I.V. (2008). Organization of the controlling system in the holding: Diss. Cand. econ. sciences.

Gabdullina, G.K. (2017). Development of methods for economic analysis and evaluation of the functioning of corporate structures in the region: monograph. Novosibirsk: Publisher CRNS. $124 \mathrm{~s}$

Development of a system of balanced scorecard for enterprises of the petrochemical complex of PJSC "Tatneft" // Modern society and power. 2016. № 3 (9). P. 168-172.
Gabdullina G.K. (2017). Analysis of Corporate Structure in Regional Firms. International Journal of Economic Perspectives, Vol.11, Issue 3.

Gabdullina G.K. (2017). Economic Feasibility of Corporate Structure Creation" International Journal of Economic Perspectives, Vol. 11, Issue 3.

Gaiser, B. (1997). International Perspectives: German Cost Management Systems, in Journal of Cost Management, Vol. 11, Sept/Oct, No.5, P.35-41

Gaiser, B., Grainer, O. (2002). Balanced Scorecard: Von der Mode zur KZunst, in: Consulting-Jahrbuch. P.101-113

Kaplan R.S., Norton D.P. (1992). The Balanced Scorecard - Measures that Drive Performance, in Harvard Business Review, Vol.70, No. 1. P.71-79

Kaplan R.S., Norton D.P. (1996). Putting the Balanced Scorecard to Work, in: Harvard Business Review, Vol. 74, Jan/Feb, No. 1, P.75-85 
Periódico do Núcleo de Estudos e Pesquisas sobre Gênero e Direito Centro de Ciências Jurídicas - Universidade Federal da Paraíba V. 8 - No 05 - Ano 2019 ISSN | 2179-7137 | http://periodicos.ufpb.br/ojs2/index.php/ged/index

Karamyshev, A.N. (2018). Analysis of

Existing Approaches to Management of

Industrial Enterprises // HELIX. Vol.8,

Is.1. P.2893-2897 